\title{
HIV- and hepatitis C-related risk behaviors among people who inject drugs in Uganda: implications for policy and programming
}

\author{
Matayo Baluku', Twaibu Wamala $2^{2^{*}}$ and Denis Muhangi ${ }^{3}$
}

\begin{abstract}
Background: There is a dearth of evidence on injecting drug use and associated HIV and hepatitis C virus (HCV) infections in Uganda. As such, policy and programming for people who inject drugs (PWID) is limited due to scarcity of epidemiological data. We therefore conducted this study to assess the injecting drug and sexual practices among PWID in Kampala Capital City and Mbale Municipality.
\end{abstract}

Methods: Using a rapid situation assessment framework, we conducted semi-structured interviews among 125 PWID (102 males and 23 females) - recruited through outreach and snowball sampling. We assessed their injecting drug and sexual practices. We also conducted 12 focus group discussions among PWID and 30 in-depth interviews among key informants.

Results: A total of 125 PWID (81.6\% males and 18.4\% females) were recruited into the study. Approximately three quarters of PWID started injecting before the age of 25. More females (21.7\%) compared to males (13.7\%) started injecting by the age of 17. Fifty-seven percent of the PWID in Kampala and 50\% in Mbale shared injecting equipment in the last 3 months prior to the study. There was an emerging practice of mixing drugs with blood and sharing it among different PWID as a sign of oneness. Heroin was being injected by $72 \%$ of the participants. Less than one half of the PWID had used a condom during the last casual sex, and $42.7 \%$ did not use a condom the last time they engaged in sex work. Seventy-six percent of the PWID had undertaken an HIV test in the last 12 months, and $9.2 \%$ self-reported to be HIV positive.

Conclusions: This study highlights the need for introducing harm reduction policies and services including increased access to sterile injecting equipment and education around safer injecting and sexual practices. Programs for PWID should also address the specific needs of female sex workers who inject drugs.

Keywords: People who inject drugs, Injecting drug use, Hepatitis C virus, HIV, Risk behavior, Heroin, Female sex workers, Harm reduction, Uganda

\section{Introduction}

Globally, an estimated 275 million people used drugs at least once in 2016, 10.9 million of whom injected their drugs [1]. Injecting drugs carries a high risk of human immunodeficiency virus (HIV) and viral hepatitis transmission if sterile injecting equipment is not easily accessible and injecting equipment is shared among users. In 2016, more than half of the people who inject drugs (PWID) worldwide were living with hepatitis $\mathrm{C}$

\footnotetext{
* Correspondence: wamala5969@gmail.com

Uganda Harm Reduction Network, Kampala, Uganda

Full list of author information is available at the end of the article
}

virus (HCV); one in eight was living with HIV, and 82.4\% were co-infected with both HIV and HCV [2-5]. The risk of acquiring HIV for PWID in 2017 was 22 times higher than that for people who did not inject drugs [6].

Whereas hepatitis B virus (HBV) and HIV are transmitted via blood or body fluids [7], sharing injecting equipment poses the greatest risk of $\mathrm{HCV}$ transmission among PWID [8]. Also, whereas there is no increased risk of $\mathrm{HCV}$ transmission in a long-term heterosexual relationship, the risk of transmission increases with multiple sexual partners and among women who are

(C) The Author(s). 2019 Open Access This article is distributed under the terms of the Creative Commons Attribution 4.0 International License (http://creativecommons.org/licenses/by/4.0/), which permits unrestricted use, distribution, and 
infected with HIV or other sexually transmitted diseases [9]. Similarly, engaging in sex work, younger age, cocaine injecting, depression, requiring help injecting, having unsafe sex with a regular partner, and having an HIVpositive sexual partner are associated with HIV infection among PWID [10-12].

Risk factors for HCV among PWID include sharing needles and other injecting equipment [13, 14], longer duration of injecting career [15], increased frequency of injection $[15,16]$, requiring help injecting $[17,18]$, being female $[15,19]$, and history of imprisonment $[15,16]$.

Despite the heavy burden of injecting drug use and its associated risks, and burden of HIV and HCV among PWID, effective harm reduction interventions that can help prevent their spread are severely lacking in many countries including Uganda [20-22]. In Sub-Saharan Africa, only eight countries operate the needle and syringe program (NSP); seven offer some form of opioid substitution therapy (OST), and ten have explicit support for harm reduction contained in national policy documents [21]. The current policies and guidelines for prevention and treatment of HIV and AIDS in Uganda do not support OST and NSP [23].

While Uganda is one of the 179 countries where injecting drug use is present $[20,21]$, data on PWID is limited. No studies have enquired about risk injecting and sexual practices for HIV and HCV among PWID. We therefore conducted this study to assess the risk practices among PWID in Uganda. We compared PWID sampled from Kampala, the only capital and central business city of Uganda, and Mbale Municipality, an urban center in Eastern Uganda.

\section{Methods}

This rapid situation assessment (RSA) [24] —conducted from February to September, 2017-was part of a broader study to establish the current situation of injecting drug use in Uganda and identify the country-specific links between injecting drug use and HIV and HCV risk. It sought to generate evidence on "what practices and behaviors increase HIV and HCV risk among PWID in Kampala and Mbale?"

The study was conducted in two different settings: Kampala Capital City and Mbale Municipality. Kampala the only capital and business city of Uganda was purposively selected because it is thought to have the biggest number of people who inject drugs in Uganda. Mbale on the other hand is one of the major towns in Eastern Uganda and a transit route from neighboring Kenya. It is a blossoming urban center [25].

An inductive approach $[26,27]$ was used for this rapid assessment, whereby initial data collected informed planning and decisions about subsequent data collection. The rationale for this approach was to allow the research team to make sense of the data collected, determine its utility and adequacy, identify gaps, and then collect additional data if necessary.

Participants of this study were required to be PWID, both male and female aged 18 years and above; had injected drugs for non-medical purposes at least once in the past 3 months; were residents within the two study sites; and had voluntarily consented to take part in the study. Those who were deemed to be high on drugs at the time of contact were rescheduled to be interviewed at another time, or if that was not possible, they were excluded. The key informants were purposively selected people presumed to have an understanding of PWID in Uganda. They included officials from the Ministry of Health, Butabika National Mental Referral Hospital, and health workers from mental health units; officers and men of the narcotics control division of Uganda Police Force and Uganda Prisons Services; and staff of civil society organizations working with PWID.

A total of 125 PWID (95 in Kampala and 30 in Mbale) recruited through snowballing and intercepts initiated by outreach workers in known drug-use areas (hotspots) participated in the study. Data was collected from them using semi-structured interviews.

Thirty in-depth interviews (IDIs) among key informants and 12 focus group discussions (FGDs) among PWID were also conducted. Seven FGDs were done in Kampala and five in Mbale. They were conducted mainly within the hotspots. Observations of the settings and environments in which injecting drug use took place were done. The research team took extensive handwritten notes during data collection. Only in a few cases was audio-recording done.

The survey collected information on sociodemographic data, drug use patterns, risk perceptions, and service utilization from PWID. The FGDs among PWID were intended to generate in-depth information about drug use behaviors and patterns, perceptions of risk, access to and utilization of HIV and harm reduction services, shared norms and meanings, and transition from non-injecting to injecting drug use. Similarly, IDIs provided information about the locations (hotspots) where injecting drug use takes place, the context of drug use, the types of drugs used, the services available and the extent to which PWID utilized them, and the links between drug use and other risk behaviors and health harms. Other outcomes for the same study are described by Platt et al. [28]. The PWID also participated in the population size estimates described elsewhere [29].

The quantitative data collected was analyzed using MS Excel and described in terms of frequencies and percentages on the different variables. We adopted the thematic analysis approach described by Braun and Clark [30] to analyze the qualitative data progressively as it was collected. It generally followed the steps outlined: organizing 
and ordering the raw data; coding the interviews; listing and sorting the data; categorizing and summarizing the data; interpreting the data; and triangulating, validating, and drawing conclusions. The information was classified according to themes and domains and presented in form of taxonomies that reveal emerging patterns.

\section{Results}

\section{Demographic characteristics of the sample}

A total of $102(81.6 \%)$ males and 23 females (18.4\%) PWID were recruited into the study. The mean age was 27.4 (females, 25.9 ; males, 27.8 ). Only $30.4 \%$ of the participants were married or living together. At least 71 (56.8\%) participants had attained a minimum of secondary education, and 17 (13.6\%) earned their living through sex work. Table 1 has details of the demographic characteristics of the participants, stratified by study area.

\section{Injecting drug practices among PWID in Kampala and Mbale}

The injecting practices of the respondents are shown in Table 2. At least $15.2 \%$ of PWID (13.7\% in Kampala and $20 \%$ in Mbale) started injecting before the age of 17. Overall, a bigger proportion of females (21.7\%) compared to that of males $(13.7 \%)$ start injecting before the age of 17 . By the age of 25 , at least $81.6 \%$ of the PWID had started injecting.

Heroin was the most injected drug in both Kampala and Mbale in the last 4 weeks preceding the study. Study participants however kept a distinction between white heroin and brown heroin (commonly referred to as brown sugar). Brown heroin was injected by $76.7 \%$ of PWID in Mbale, while in Kampala, the same proportions (34.7\%) had injected brown heroin as white heroin. When participants were asked which drug they had injected most frequently in the past, $57.9 \%$ in Kampala mentioned brown heroin, compared to $28.4 \%$ who mentioned white heroin. We understood that brown heroin/ brown sugar was an adulterated or impure form of heroin.

The dominance of brown heroin is attributed to its cheaper cost compared to white heroin, and it could be both smoked and injected. At least $57 \%$ of all respondents shared needles and syringes, and only $30.4 \%$ used a needle once before disposal. Heroin was injected by $72 \%$ of the participants. PWID in both Kampala and Mbale use a concoction of antiretroviral drugs (ARVs) meant for the treatment of AIDS mixed with diazepam-a sedative.

Qualitative results indicated an emerging practice of sharing blood of individuals who are already "high" on drugs or mixing drugs with blood as a sign of oneness as well as wide spread of sharing of injecting equipment:

"we are one blood ... one brotherhood, if our colleague is already high, we can draw his blood and
Table 1 Demographic characteristics of the participants

\begin{tabular}{|c|c|c|}
\hline \multirow[t]{2}{*}{ Characteristic } & Kampala & Mbale \\
\hline & Number (\%) & Number (\%) \\
\hline \multicolumn{3}{|l|}{ Biological sex of participant } \\
\hline Male & $77(81.1)$ & $25(83.3)$ \\
\hline Female & $18(18.9)$ & $5(16.7)$ \\
\hline \multicolumn{3}{|l|}{ Age of participant } \\
\hline $18-24$ & $32(33.7)$ & $12(40.0)$ \\
\hline $25-29$ & $35(36.8)$ & $16(36.7)$ \\
\hline $30-34$ & $15(15.8)$ & $3(10.0)$ \\
\hline 35 and above & $13(13.7)$ & $4(13.3)$ \\
\hline \multicolumn{3}{|l|}{ Marital status } \\
\hline Never married/single & $47(49.5)$ & $17(56.7)$ \\
\hline Married or living together & $28(29.5)$ & $10(33.3)$ \\
\hline Divorced/separated & $19(20.0)$ & $3(10.0)$ \\
\hline Widowed & $1(1.1)$ & $0(0.0)$ \\
\hline \multicolumn{3}{|l|}{ Highest level of education } \\
\hline No education & $3(3.2)$ & $0(0.0)$ \\
\hline Primary incomplete & $19(20.0)$ & $7(23.3)$ \\
\hline Completed primary education & $23(24.2)$ & $2(6.7)$ \\
\hline Secondary & $34(35.8)$ & $16(53.3)$ \\
\hline Post-secondary & $16(16.8)$ & $5(16.7)$ \\
\hline \multicolumn{3}{|l|}{ Occupation of respondent } \\
\hline Artisan/builder/carpenter/mechanic & $19(20.0)$ & $4(13.3)$ \\
\hline Temporary/informal/casual work & $9(9.5)$ & $13(43.3)$ \\
\hline Sex work & $15(15.8)$ & $2(6.7)$ \\
\hline Transporter & $15(15.8)$ & $0(0.0)$ \\
\hline Trade/business & $9(9.5)$ & $2(6.7)$ \\
\hline Entertainer/artist & $8(8.4)$ & $0(0.0)$ \\
\hline Fishing & $7(7.4)$ & $0(0.0)$ \\
\hline Salon/beauty/health club & $3(3.2)$ & $0(0.0)$ \\
\hline Student & $0(0.0)$ & $2(6.7)$ \\
\hline Bar/hotel worker & $0(0.0)$ & $1(3.3)$ \\
\hline Other & $4(4.2)$ & $5(16.7)$ \\
\hline None & $6(6.3)$ & $1(3.3)$ \\
\hline
\end{tabular}

inject ourselves to get high too ... " PWID FGD, Bwaise

"... cannot have this drug and fail to share with my brother here because I know at one time I will not have money and he will share with me so for us here we are all brothers and we are one family" FGD, PWID, Kawempe

“drugs are expensive sometimes we don't change needles in order to avoid losing any drop of the drug" FGD, MSM PWID, Mbale 
Table 2 Participants' injecting drug practices

\begin{tabular}{lrl}
\hline Injecting practices & $\begin{array}{r}\text { Kampala } \\
\text { Freq (\%) }\end{array}$ & $\begin{array}{l}\text { Mbale } \\
\text { Freq } \\
(\%)\end{array}$ \\
\hline $\begin{array}{ll}\text { Age first injected } \\
10-17\end{array}$ & $13(13.7)$ & 6 \\
$18-24$ & $63(66.3)$ & 20 \\
& & $(66.7)$ \\
$25+$ & $19(20.0)$ & 4 \\
& & $(13.3)$
\end{tabular}

Type of drug injected in the past 4 weeks

Brown heroin

White heroin

Cocaine

Morphine

Pethidine

Antiretroviral medications + diazepam

Other

Number of times a needle was used before disposal

1

$2-4$

$5-9$

$10+$

Do not know/do not remember

Number of times a syringe was used before disposal

1

$2-4$

$5-9$

$10+$

Do not know/do not remember

Sharing practices

Injected using needles/syringes used by someone else

Injected using a syringe after someone has squirted into it from their syringe (frontloading/ backloading/splitting)

Used a filter or cotton into which someone else had previously used to draw up drugs with their needle/syringe

Drew up drug solution into syringe from a mixing container (spoon or glass) from which someone else had previously drawn up (16.7)

$19(20.0) \quad 1(3.3)$

$3(3.2) \quad 0(0.0)$

$0(0.0) \quad 2(6.7)$

$2(2.1) \quad 2(6.7)$

$5(5.3) \quad 3$

$28(29.5) \quad 10$

$41(43.2) \quad 15$ (50.0)

12 (12.6) 1 (3.3)

13 (13.7) $1(3.3)$

$1(1.1) \quad 3$

27 (28.4) 6

36 (37.9) 12 (40.0)

$10(10.5) 7$ (23.3)

20 (21.1) $2(6.7)$

2 (2.1) 3 (10.0)

57 (60) 15 (50)

59 (62.1) 13 (43.3)

43 (45.3) 4 (13.3)

$64(67.4) \quad 15$ (50)
Sexual practices among PWID in Kampala and Mbale

On average, more than a half of the respondents had sex with two or more partners in the month preceding the study. Only $47 \%$ had used a condom during the last casual sex, and of the 65 participants who had sold or bought sex, only $54 \%$ used a condom. Details of practices are provided in Table 3.

\section{Discussion}

This study is the first to report population-based risk behaviors among PWID in Kampala Capital City and Mbale Municipality, Uganda. Our findings indicate high $\begin{array}{lll}33(34.7) & 23 & \text { levels of risky injection behaviors. The median age at } \\ & \text { (76.7) } & \text { first injection was } 19(14-25) \text { with } 15.2 \% \text { of the partici- }\end{array}$ 33 (34.7) 5 pants having started injecting by the age of 17 and $81.6 \%$ before the age of 25 . This age was comparable to similar studies conducted in South Africa [31, 32]. Other studies have found out that up to $45 \%$ of the PWID began injecting before they were 15 years old [33]. While most studies on PWID exclude young people aged 15-24 especially those under the age of 18 [34], it is important to note that injecting drug use in this age group is important because early onset of injecting, and being a new injector, has been associated with increased risks of HIV and hepatitis $\mathrm{C}$ transmission [35]. For some young people, drug use is a part of adolescent experimentation, socialization, risk taking, and reward seeking, particularly in the presence of peers [36]. They are more likely to inject drugs in groups and to share injecting equipment as they might not be able to afford to buy their own [36, 37, 38]. Young people who inject drugs in Uganda, including those below the age of 18, will need special attention for harm reduction programming as well as research.

This study established that three in every five PWID in Kampala and one in two PWID in Mbale share injecting

Table 3 Participants' sexual practices

\begin{tabular}{lll}
\hline Sexual practice & $\begin{array}{l}\text { Kampala } \\
n(\%)\end{array}$ & $\begin{array}{l}\text { Mbale } \\
n(\%)\end{array}$ \\
\hline $\begin{array}{l}\text { Had sex with } 2 \text { or more partners } \\
\text { in the last } 30 \text { days }\end{array}$ & $46(48.4)$ & $18(60.0)$ \\
$\begin{array}{l}\text { Used a condom at the last casual } \\
\text { sex }\end{array}$ & $45(47.4)$ & $14(46.7)$ \\
$\begin{array}{l}\text { Used a condom the last she/he } \\
\text { bought or sold sex }\end{array}$ & $25(50 \%)$ & $10(66.7)$ \\
$\begin{array}{l}\text { Ever had sex with someone of the } \\
\text { same sex }\end{array}$ & $2(2.2)$ & $1(3.3)$ \\
$\begin{array}{l}\text { Exchange sex for money, drugs, or } \\
\text { gifts in the last } 6 \text { months }\end{array}$ & $10(10.5)$ & $4(13.3)$ \\
Had HIV test in the last 12 months & $76(80)$ & $19(63.3)$ \\
Self-reported HIV positive & $7(9.2)$ & $0(0.0)$ \\
Have a non-injecting partner & $58(61.1)$ & $18(60.0)$ \\
\hline
\end{tabular}


equipment. Sharing of injecting equipment is well studied as a high risk practice for transmission of HIV and viral hepatitis $[4,8,13]$. Limited access to new syringes and needles and limited knowledge on the risks were important contributors to the behaviors. This, in case of Uganda, is worsened by the lack of a policy framework under which to provide such services. Studies have suggested that knowledge gap especially for HCV transmission among PWID also contributed to its high prevalence [39-41]. Similar studies in Nairobi, Kenya, also established that HIV was independently associated with lifetime practice of using previously used needles and syringes and longer time since first injection [42], while one in South Africa [31] did not. They, like others before, highlight the lack of needle and syringe programs and criminalization of PWID as contributing factors to high risk injecting behaviors [32, 43].

Sexual risk behaviors are also significant among PWID in Uganda due to multiple sex partners, irregular use of condoms, and selling of sex. Female participants, like in most studies, were more likely to sell sex than men. Sex work is a common means to support drug use and that of their partners, and sex workers might use drugs to enhance sexual performance and as a coping strategy-to obtain courage to approach clients and stand the cold on the streets. Additionally, use of certain drugs may increase sexual desire or lower behavioral inhibitions, further affecting risk perception [44-46].

The study also established that the self-reported HIV prevalence among PWID in Kampala, at 9.2\%, is still higher than the national prevalence of $6.2 \%$ [47]. Given that over $60 \%$ of the PWID had non-injecting partners, the likelihood of bridging to the general population is high.

\section{Limitations}

Firstly, the study was conducted in only two sites, that is, Kampala and Mbale, even though there is a lack of data on a national scale. Secondly, the study focused on $\mathrm{HIV}$ and HCV, leaving out other equally important infections such as tuberculosis and HBV infection. Further, in this study, we did not interview PWID under the age of 18 , although they exist, neither did we access the middle/upper class or corporate PWID. Lastly, we did not test blood for HIV and HCV but only relied on selfreported test results. Some studies have suggested that self-reported HIV test results are likely to be inaccurate due to the effects of social desirability bias and post-test seroconversion [48], or when respondents fail to understand the meaning of a positive or negative test result and fail to remember the result [49]. Similarly, routine service utilization data, like most sentinel surveillance data [50], are from non-random samples and might not be representative of the prevalence of $\mathrm{HIV}$ and $\mathrm{HCV}$ among the PWID.

Despite the above limitations, the results generated by the study still provide reliable and useful insights into the dynamics and risks of injecting drug use in Kampala and Mbale towns.

\section{Conclusion}

Our findings indicate injecting drug use is a growing problem in Kampala Capital City and Mbale Municipality. PWID reuse and share injecting equipment, as well as mix drugs with blood and share the mixture. PWIDs also engage in risky sexual practices including multiple partners, irregular condom use, and sex work. These are high risks for HIV and HCV infection. With over $60 \%$ of sexually active PWID having non-injecting sex partners, PWID can potentially fuel the HIV and viral hepatitis epidemic in the general and non-injecting population in Uganda.

\section{Implications for policy and programming}

Given the gravity of the risks of injecting drug use in Uganda and lack of comprehensive interventions for PWID, the Ministry of Health should embrace harm reduction-including OST and NSP, as the overarching strategy to respond to drug injecting-related risks and harms. This calls for putting in place policy provisions, guidelines, and financial allocations that support the provision of comprehensive harm reduction services.

The study indicates how initiation of injecting drug use occurs in over $80 \%$ of the PWID in Uganda by the age of 24. As such, harm reduction awareness should be mainstreamed in programs of adolescents and young people.

Due to limited geographically specific data on PWID, similar studies should be conducted for other major towns of Uganda and should include biomarkers for HIV and viral hepatitis testing.

\section{Abbreviations}

FGDs: Focus group discussions; HCV: Hepatitis C virus; HIV: Human immunodeficiency virus; IDI: In-depth interviews; MARPI: Most At Risk Populations Initiative; NSP: Needle and syringe program; PWID: People who inject drugs; TASO: The AIDS Support Organization

\section{Acknowledgements}

We thank Peter Byansi, Symon Peter Byandiembe, David Bitira, Vivian Nsubuga, Rodgers Amperwa, Gracias Atwine, and Ben Mundia; the Uganda Ministry of Health and Uganda AIDS Commission; MARPs Network and Alliance of Mayors and Municipal Leaders on HIV/AIDS in Africa (AMICAALL) Uganda; Butabika National Referral Hospital, Uganda Police Force, and Uganda Prisons Service; Kenyan AIDS NGOS Consortium (KANCO); and London School of Hygiene and Tropical Medicine.

\section{Authors' contributions}

MD designed the study with input from WT and MB. MB completed the analysis and led the writing of the manuscript. All authors reviewed and contributed to the manuscript. All authors read and approved the final manuscript. 


\section{Funding}

The funding for this study was provided for through Kenyan AIDS NGOS Consortium as sub-recipient of Globe Fund for AIDS, TB, and Malaria.

\section{Availability of data and materials}

The datasets used and/or analyzed during this study are available from the corresponding author on reasonable request.

\section{Ethics approval and consent to participate}

The study obtained ethical approval from the Mildmay Research Ethics Committee (MUREC) and was registered by the Uganda National Council for Science and Technology (UNCST). All participants provided informed consent to participate in the study.

\section{Consent for publication}

The participants consented to the use of their data for research publications.

\section{Competing interests}

The authors declare that they have no competing interests.

\section{Author details}

${ }^{1}$ Infectious Diseases Institute, College of Health Sciences, Makerere University, Kampala, Uganda. ${ }^{2}$ Uganda Harm Reduction Network, Kampala, Uganda.

${ }^{3}$ School of Social Sciences, Makerere University, Kampala, Uganda.

\section{Received: 14 May 2019 Accepted: 21 August 2019}

Published online: 03 September 2019

\section{References}

1. UNODC. World drug report 2018. Vienna: UNODC; 2019.

2. UNAIDS. Health, rights and drugs: harm reduction, decriminalization, and zero discrimination for people who use drugs. Geneva: Joint United Nations Programme on HIV/AIDS; 2019

3. Degenhardt L, Peacock A, Colledge S, Leung J, Grebely J, Vickerman P, Stone J, Cunningham BE, Trickey A, Dumchev K, et al. Global prevalence of injecting drug use and sociodemographic characteristics and prevalence of $H I V, H B V$, and HCV in people who inject drugs: a multistage systematic review. Lancet Glob Health. 2017:5:e1192-207.

4. World Health Organization. Global Hepatitis Report 2017. Geneva: World Health Organisation; 2017.

5. Larney S, Peacock A, Leung J, Colledge S, Hickman H, Vickerman P. Global, regional and country-level coverage of interventions to prevent and manage HIV and hepatitis C among people who inject drugs: a systematic review. Lancet. 2017;5(12):PE1208-20.

6. UNAIDS. Global AIDS report 2018. Miles to go: closing gaps, breaking barriers, righting injustices. In: Geneve United Nations Programme on HIV/ AIDS; 2018.

7. Gilchrist G, Swan D, Shaw A, Keding A, Towers S, Craine N, Munro A Hughes E, Parrott S, Mdege N, et al. Preventing blood-borne virus infection in people who inject drugs in the UK: systematic review, stakeholder interviews, psychosocial intervention development and feasibility randomised controlled trial. Health Technol Assess. Southampton. 2017;21:1311. https://doi.org/10.3310/hta21720

8. Palmateer N, Hutchinson S, McAllister G, Munro A, Cameron S, Goldberg D. Risk of transmission associated with sharing drug injecting paraphernalia: analysis of recent hepatitis C virus ( $\mathrm{HCV}$ ) infection using cross-sectional survey data. J Viral Hepat. 2014;21:25-32.

9. Tohme R, Holmberg S. Is sexual contact a major mode of hepatitis C virus transmission? Hepatology. 2010;52:1497-505

10. Strathdee S, Galai N, Safaiean M, Celentano D, Vlahov D, Johnson L, Nelson K. Sex differences in risk factors for HIV seroconversion among injection drug users: a 10-year perspective. Arch Intern Med. 2001;161:1281-8.

11. Gilchrist G, Blazquez A, Torrens M. Psychiatric, behavioural and social risk factors for HIV infection among female drug users. AIDS Behav. 2011;15: 1834-43.

12. O'Connell J, Kerr T, Li K, Tyndall M, Hogg R, Montaner J, Wood E. Requiring help injecting independently predicts incident HIV infection among injection drug users. J Acquir Immune Defic Syndr. 2005;40:83-8.

13. Corson S, Greenhalgh D, Taylor A, Palmateer N, Goldberg D, Hutchinson S. Modelling the prevalence of HCV amongst people who inject drugs: an investigation into the risks associated with injecting paraphernalia sharing Drug Alcohol Depend. 2013;133:172-9.

14. HIV Among People Who Inject Drugs [https://www.cdc.gov/hiv/group/hividu.html]. Accessed 5 Apr 2019.

15. Judd A, Hutchinson S, Wadd S, Hickman M, Taylor A, Jones S, Parry J, Cameron S, Rhodes T, Ahmed S, et al. Prevalence of, and risk factors for, hepatitis $C$ virus infection among recent initiates to injecting in London and Glasgow: cross sectional analysis. J Viral Hepat. 2005;12:655-62.

16. Backmund M, Meyer $K$, Wächtler M, Eichenlaub D. Hepatitis C virus infection in injection drug users in Bavaria: risk factors for seropositivity. Eur J Epidemiol. 2003;18:563-8.

17. Bryant J, Brener L, Hull P, Treloar C. Needle sharing in regular sexual relationships: an examination of serodiscordance, drug using practices, and the gendered character of injecting. Drug Alcohol Depend. 2010;107:182-7.

18. Jolley E, Rhodes T, Platt L, Hope V, Latypov A, Donoghoe M, Wilson D. HIV among people who inject drugs in Central and Eastern Europe and Central Asia: a systematic review with implications for policy. BMJ Open. 2012;2:e001465.

19. Vescio M, Longo B, Babudieri S, Starnini G, Carbonara S, Rezza G, Monarca R. Correlates of hepatitis $C$ virus seropositivity in prison inmates: a metaanalysis. J Epidemiol Community Health. 2008;62:305-13.

20. Larney S, Peacock A, Leung J, Colledge S, Hickman M, Vickerman P. Global, regional, and country-level coverage of interventions to prevent and manage HIV and hepatitis C among people who inject drugs: a systematic review. Lancet Glob Health. 2017;5(12):e1208-20.

21. Stone K, Shirley-Beavan S. Global state of harm reduction 2018. London: Harm Reduction International; 2018.

22. Uganda AIDS Commission. National HIV and AIDS strategic plan 2015/152019/20. Kampala: Uganda AIDS Commission; 2015.

23. Ministry of Health. Consolidated guidelines for prevention and treatment of HIV and AIDS in Uganda. 2nd ed. Kampala: Ministry of Health; 2018.

24. Rhodes T, Stimson GV, Fitch C, Ball A, Renton A. Rapid assessment, injecting drug use, and public health. Lancet. 1999;354(9172):65-8.

25. Uganda Bureau of Statistics. The National Population and Housing Census 2014 - main report. Kampala: Uganda Bureau of Statistics; 2016.

26. Inductive and deductive approaches to research. [http://deborahgabriel. com/2013/03/17/inductive-and-deductive-approaches-to-research/]. Accessed 5 Apr 2019.

27. Thomas RD. A general inductive approach for analyzing qualitative evaluation data. Am J Eval. 2006;27(2):237-46.

28. Platt $L$, Stengel CM, Nkurunziza $M$, Muhangi $D$, Byansi $P$, Wandiembe $P$, Busago A, Bitira D, Mundia B, Mlewa O, et al. Assessing risk of HIV and hepatitis $C$ among people who inject drugs in East Africa: findings from a rapid assessment. J Viral Hepat. 2019;00:1-4

29. Baluku M, Wamala T, Muhangi D, Namanya B. Counting that counts: estimating the number of people who inject drugs in two urban centers in Uganda: ResearchGate; 2019. https://doi.org/10.13140/RG.2.2.12388.22406; https://www.researchgate.net/publication/332151737_Counting_that counts_Estimating_the_number_of_People_Who_Inject_Drugs_in_two_ urban_centers_in_Uganda.

30. Braun V, Clark V. Using thematic analysis in psychology. Qual Res Psychol. 2006:3(2):77-101.

31. Scheibe A, Makapela D, Brown B, dos Santos M, Hariga F, Virk H, Bekker L, Lyan O, Fee N, Molnar M, et al. HIV prevalence and risk among people who inject drugs in five South African cities. Int J Drug Policy. 2016;30:107-15.

32. Plüddemann A, Parry CDH, Alan JF, Jordaan E. Heroin users in Cape Town, South Africa: injecting practices, HIV-related risk behaviors, and other health consequences. J Psychoactive Drugs. 40(3):273-79.

33. Busza J, Douthwaite M, Bani R, Scutelniciuc O, Preda M, Simic D. Injecting behaviour and service use among young injectors in Albania, Moldova, Romania and Serbia. Int J Drug Policy. 2013;24(5):423-31.

34. Organization WH. HIV and young people who inject drugs: technical brief. Geneva: World Health Organization; 2015.

35. Barrett D, Hunt N, Stoicescu C. Injecting drug use among under 18s: a snapshot of available data. Harm Reduction International: London; 2013.

36. United Nations Office on Drugs and Crime and Global Youth Network. HIV Prevention Among Young Injecting Drug Users. NewYork, United Nations. 2004. Its available at https://www.unodc.org/documents/hiv-aids/ publications/HIV_Prevention_among_Young_Injecting_Drug_Users.pdf.

37. Rhodes T, Bivol S, Scutelniciuc O, Hunt N, Bernays S, Busza J. Narrating the social relations of initiating injecting drug use: transitions in self and society. Int J Drug Policy. 2011;22(6):445-54. 
38. Grund J-P, Merkinaite S, editors. Young people and injecting drug use in selected countries of Central and Eastern Europe. Vilnius: Eurasian Harm Reduction Network; 2009.

39. O'Brien S, Day C, Black E, Dolan K. Injecting drug users' understanding of hepatitis C. Addict Behav. 2008:33:1602-5.

40. Cohen-Moreno R, Schiff M, Levitt S, Bar-Hamburger R, Strauss S, Neumark Y. Knowledge about hepatitis-C among methadone maintenance treatment patients in Israel. Subst Use Misuse. 2010;45:58-76.

41. Treloar C, Hull P, Bryant J, Hopwood M, Grebely J, Lavis Y. Factors associated with hepatitis $C$ knowledge among a sample of treatment naive people who inject drugs. Drug Alcohol Depend. 2011;116:52-6.

42. Tun W, Sheehy M, Broz D, Okal J, Muraguri N, Raymond HF, Musyoki H, Kim AA, Muthui M, Geibel S. HIV and STI prevalence and injection behaviors among people who inject drugs in Nairobi: results from a 2011 bio-behavioral study using respondent-driven sampling. AIDS Behav. 2015;19:S24-35.

43. Parry C, Petersen P, Carney T, Dewing S, Needle R. Rapid assessment of drug use and sexual HIV risk patterns among vulnerable drug-using populations in Cape Town, Durban and Pretoria, South Africa. Sahara J. 2008:5(3):13-9.

44. Azim T, Bontell I, Strathdee S. Women, drugs and HIV. Int I Drug Policy. 2015;26(Suppl 1):S16-21.

45. Ditmore HM. When sex work and drug use overlap: considerations for advocacy and practice. London: Harm Reduction International; 2013.

46. World Health Organization. Technical brief: HIV and young people who sell sex. Geneva: World Health Organization; 2015.

47. UPHIA. Uganda population-based hiv impact assessment: summary sheet, preliminary findings. Kampala: Ministry of Health, Centers for Diseases Control and Prevention; 2017. https://www.afro.who.int/sites/default/files/2 017-08/UPHIA\%20Uganda\%20factsheet.pdf.

48. Johnston GL, Sabin LM, Prybylski D, Sabin K, McFarland W, Baral S, Kim AA, Raymond $\mathrm{FH}$. The importance of assessing self-reported HIV status in biobehavioural surveys. Bull World Health Organ. 2016;94:605-12.

49. Sanchez T, Kelley C, Rosenberg E, Luisi N, O'Hara B, Lambert R, Coleman R, Frew P, Salazar FL, Tao S, et al. Lack of awareness of human immunodeficiency virus (HIV) infection: problems and solutions with selfreported HIV serostatus of men who have sex with men. Open Forum Infect Dis. 2014:1(2):ofu084.

50. Brookmeyer R. Measuring the HIV/AIDS epidemic: approaches and challenges. Epidemiol Rev. 2010;32(1):26-37.

\section{Publisher's Note}

Springer Nature remains neutral with regard to jurisdictional claims in published maps and institutional affiliations.

Ready to submit your research? Choose BMC and benefit from:

- fast, convenient online submission

- thorough peer review by experienced researchers in your field

- rapid publication on acceptance

- support for research data, including large and complex data types

- gold Open Access which fosters wider collaboration and increased citations

- maximum visibility for your research: over $100 \mathrm{M}$ website views per year

At $\mathrm{BMC}$, research is always in progress.

Learn more biomedcentral.com/submissions 